\title{
The concept of illness in the physician-patient relationship
}

\author{
Florindo Pirone \\ Dirigente f.r. Ospedale Sandro Pertini, Roma, Italy
}

On disease we can say what Aurelio Agostino d'Ippona affirmed in his famous quote about time What is then time? If no one asks, I know it very well: but if I tried to explain it to whom asks, I wouldn't know...

The concept of illness - tough seemingly clear to everyone - is in reality a complex notion, which is hard to define. A concept that also changes during the history of humankind and its meanings echo significantly in the relationship between doctors and their patients.

The physician-patient relationship, as all human relations, depends on several factors to be considered both single-handedly and among each other, which determine its main characteristics. There's a shared belief that the worldview (Weltanschauung) connected to illness or to its opposite - health - is a fundamental factor acting in this specific type of relationship.

Without claiming to cover all aspects of such a wide topic, ${ }^{1}$ I consider useful to describe all changes undergone by the concept of illness starting from the second half of the last century until today, and how these changes have themselves modified the relations between physicians and their patients. This analysis rests on an elementary, purely descriptive approach and it is not based on a systematic theory or history-

Correspondence: Florindo Pirone, via Vaglia 71, 00139 Roma, Italy.

Tel.: +39.06.86891985. E-mail: florindo.pirone@virgilio.it

Key words: Disease; illness; physician-patient relationship.

Conflict of interest: the authors declare no potential conflict of interest.

Received for publication: 13 February 2018.

Revision received: 12 May 2018.

Accepted for publication: 21 May 2018.

This work is licensed under a Creative Commons Attribution NonCommercial 4.0 License (CC BY-NC 4.0).

C Copyright F. Pirone, 2018

Licensee PAGEPress, Italy

Italian Journal of Medicine 2018; 12:227-229

doi:10.4081/itjm.2018.992 related presentation. This, I believe, has the merit of presenting a common and effective worldview of the idea of illness and the physician-patient relationships deriving from it. ${ }^{2,3}$

In the 60 s and 70 s, a crucial change had already taken place in our education and training: in the period following World War II, significant steps were taken with regard to the progress of knowledge in the diagnostic and therapeutic fields. Therapeutic nihilism had been overcome: physicians of the first half of the century in fact had to helplessly witness the insurgence of many diseases. Physicians' intervention had been very limited and could be summed up under the three $P$ 's: $p$ lacebo, palliative care, and purgative remedies; as well as bed, wool and milk.

Only in the second half of the century, with the advent of antibiotics (the magic bullets) real cures for patients became available.

The model of the infectious disease - whose specific external agent could be identified and tackled - was the prevailing model of illness during the long period of time when epidemiology was dominated by these kinds of diseases, thus confirming the common definition of disease as an alteration of biological structures or functions.

It was this concept of disease that - even if implicitly - was imparted in those years of education and professional training. [Some level of criticism has been raised also against this apparently simple definition. For example, hereditary variations of the red blood cells, such as thalassemia and sickle cells anemia, are considered pathological for the related altered functioning of the $P R B C \mathrm{~s}$ and the increase of the mortality rate of patients affected by these genes. However, the very same mutant genes causing these anomalies protect the individuals that have them from the mortal effects of malaria, a disease caused by a parasite infecting red blood cells. This protection reduces mortality of the patients located in areas with high rate of malaria; whereas in other environments these genes cause higher mortality.]

But when this kind of illness was adequately controlled, if not defeated, degenerative and neoplastic diseases started to appear, which would not often fit in the fixed model of a disease caused by a specific 
external agent. The health balance could be broken due to multiple factors, which may arise from the very same organism they were attacking, as for instance the autoimmune disease and heteroplasia related to genetic mutation.

Linked with the timeline of these fundamental changes in the concept of disease, in October 1986 in the city of Ottawa, Canada, the First International Conference on Health Promotion took place, resulting in what is known today as the Ottawa Charter for Health Promotion. It states that the concept of health is: a state of complete physical, social and mental wellbeing and not merely the absence of a disease or mental illness. ${ }^{4}$

At that time many people considered this definition as delusive due to its aspiration to a state of complete wellbeing, which is unachievable.

Yet indeed, this definition represented an expansion of the concept of disease from a mere alteration of a biological structure or function to those personal phenomenological (mental wellbeing) and collective (social wellbeing) aspects. This conceptual expansion was accompanied by a progressive development of instrumental and pharmacological capabilities of medicine, both in the diagnostic and therapeutic fields.

We have then moved from the individual medicine based on the doctor to be called in by the patient (following the old saying medicus non accedat nisi vocatur) to a proactive approach with doctors advising the general public to do screenings as if they were searching for patients to cure. The idea of disease as alteration of biological structures or functions was progressively associated with (and in some instances substituted by) deviation from the norm. Regardless of the symptoms or ailments lamented by the patient, some laboratory or instrumental parameters represented the determining factor.

In the 90 s the concept of disease underwent an additional expansion - still ongoing - thanks to the opportunity to go deeper and deeper in the investigation of the human body, to the point of using probes capable of drawing maps of genes predictive of probable diseases, many years before they would appear, generating doubts on how to manage such conditions.

The changes in the idea of disease have been accompanied by a rising economic crisis and a struggle (or impossibility) to manage specific diseases ever so widespread and costly in their diagnosis and treatment. The vision of what a disease really is, or a simple non-treatable variation, had to deal with these economic aspects (for example, a woman's infertility due to causes that could be solved by costly treatments is to be considered as a disease or a personal dissatisfaction).
The same question could be asked with regard to specific lifestyles such as alcohol consumption or smoking cigarettes, as their biological consequences (lung- and liver-related diseases) were ascribed to individual behavior rather than to specific health treatments provided to and paid by the public.

In the latter part of the last century and in the first half of the new one, two determining factors of the relations between doctors and their patients have arisen: information technology (IT) and the standardization of such relations by designed protocols.

At the beginning, the relation between patient and doctor was direct, with the first asking the second for help, and the second - by science and moral integrity - coming up with solutions deemed most appropriate for that instance. Currently, the relation has been mediated: the patient is no longer activating the request for the doctor's intervention spontaneously, and the latter now has to go through several regulation limits (definition of health issues requiring assistance, the duration of the recommended assistance, the levels of public expenditure, the established therapeutic protocols, etc.).

Underlying these latest changes, there seems to be a common element throughout this evolution: a progressive reduction of the patient from a person characterized by different dimensions (somatic, psychological, spiritual, social) to only one dimension: the biological and mechanical one, quantifiable through measuring systems available from technology (and from his/her interests).

The dramatic and pervasive development of science, from the study of genes to IT, has broken the relation between people and the world they live in, which has often become distressing. Physics Nobel prize winner Steven Weinberg has said insightful: The more comprehensible the universe may appear to us, the more it is indeed meaningless. ${ }^{5}$

All this has produced the deepening of the phenomenon known as iatrogenesis, as a negative consequence on the psychological and social level of the excessive medicalization of life. Every step of the so-called and mentioned medical advance has induced its peculiar feature of iatrogenesis. This has also profoundly changed the general attitude towards medicine and has led physicians to recast their professional education in this field. ${ }^{6,7}$

This is exactly the opposite of the concept of vis medicatrix naturae, ${ }^{8}$ which was still present in the idea of disease in the first half of the last century, conceiving man in harmony and balance with the universe. ${ }^{9}$ This holistic vision was embraced by the practices known as alternative and complementary medicine, deemed irrational by traditional medicine, which however take into great consideration essential and deep needs of humankind. ${ }^{10}$ 
Fundamental human characteristics such as a sense of frailty and the awareness of one's own limitations, which, in an increasingly secularized age, could not seem to find support from the previous traditional spiritual perspectives. Against these psychological uncertainties, an increasingly widespread and unjustified expectation on the power of technology and medicine has arisen. Consequence of these latest changes could also be the paradoxical condition for which such an efficient medicine, as never before, is associated with such a widespread dissatisfaction (we have never been this well and we never felt this bad).

\section{References}

1. Agostino. Le confessioni, XI, 14-18. Bologna: Zanichelli; 1968. pp. 759.

2. Federspil G, Vettor R, Tenconi MT, Bellagamba A. Malattia - Universo del Corpo. Enciclopedia Treccani; 2000. Available from: http://www.treccani.it/ enciclopedia/malattia_\%28Universo-del-Corpo\%29/
3. Gregory S. Medico-paziente: un rapporto in crisi - XXI Secolo. Enciclopedia Treccani; 2010. Available from: http://www.treccani.it/enciclopedia/medico-pazienteun-rapporto-in-crisi_\%28XXI-Secolo\%29/

4. World Health Organization (WHO). Ottawa Charter for Health Promotion; 1986. Available from: http:// www.euro.who.int/_data/assets/pdf_file/0004/129532/ Ottawa_Charter.pdf?ua=1

5. Weinberg S. I primi tre minuti. Milano: Mondadori; 1990. pp. 170.

6. Smith R. Limits to medicine. Medical nemesis: the expropriation of health. J Epidemiol Commun Health 2003;57:928.

7. Cerecedo Perez MJ. Medicalization of life at GP level: were we headed to? Aten Primaria 2013;45:536-40.

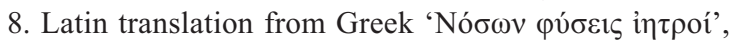
wrongly attributed to Hippocrates.

9. Hirosh H. On Vis medicatrix naturae and Hippocratic idea of physis. Memoirs of School of Health Sciences, Faculty of Medicine (Kanazawa University); 1998, 22:45-54.

10. Zarifian E. Éloge du placebo. Actual Méd Int Psychiatr 1987;48:1187-8 